\title{
IN VITRO ANTHELMINTIC ACTIVITY OF ABUTILON THEOPHRASTI MEDIK. (MALVACEAE) AGAINST EGGS AND $\mathrm{L}_{3}$ LARVAE OF HAEMONCHUS CONTORTUS
}

\author{
MUSHEERUL HASSAN ${ }^{1}$, MIR RA ${ }^{2}$, TRIPTI JOSHI ${ }^{3}$, FIRDOUS AHMAD YATOO ${ }^{4}$, HUMA HABIB ${ }^{5 *}$
}

${ }^{1}$ Deparment of Life Science, Pacific University, Udaipur, Rajasthan, India. ${ }^{2}$ Department of Zoology, Islamia College of Science and Commerce, Srinagar, Jammu and Kashmir, India. ${ }^{3}$ Department of Fire and Safety Pacific University, Udaipur, Rajasthan, India. ${ }^{4}$ Department of Botany, Bhagwant University, Ajmer, Rajasthan, India. ${ }^{5}$ Department of Biochemistry, Islamia College of Science and Commerce, Srinagar, Jammu and Kashmir, India. Email: huma99@gmail.com

Received: 24 September 2018, Revised and Accepted: 09 January 2019

\section{ABSTRACT}

Objective: The present study was carried out to assess the in vitro anthelmintic activity of Abutilon theophrasti stem extracts.

Methods: Simple maceration was employed for extraction. Solvents such as methanol, water, and hexane were used. Egg hatch test (EHT) and larval motility test were employed to check the anthelmintic activity of crude extracts. Concentrations of 500, 250, 125, 62.5, and 31.25 mg/ml were made. Levamisole and distilled water served as control, respectively.

Results: All selected extracts displayed concentration-dependent inhibition except aqueous extracts. At higher concentration (500 mg/ml), stem extracts (methanol, aqueous, and ethanol) showed 74.39\%, 72.5 and $70.03 \%$ of efficacy in EHT, respectively ( $\mathrm{p} \leq 0.05)$. Meanwhile, inhibition of larval motility was seen higher with inhibition percentage of $79.79,75.65$, and 71.28 by methanolic, aqueous, and hexane extracts, respectively ( $p \leq 0.05$ ).

Conclusion: The presents study suggests active principles having anthelmintic efficacy in Abutilon theopharsti stem.

Keywords: Haemonchus contortus, Egg hatch test, Larval motility test.

(C) 2019 The Authors. Published by Innovare Academic Sciences Pvt Ltd. This is an open access article under the CC BY license (http://creativecommons. org/licenses/by/4. 0/) DOI: http://dx.doi.org/10.22159/ajpcr.2019.v12i3.29922

\section{INTRODUCTION}

Helminthiasis is one of the most important animal diseases worldwide, inflicting heavy production losses on grazing animals. Nematodes infect gastrointestinal tract adversely of small ruminants all over the world, especially in tropical and subtropical countries, and affect the overall productivity. The disease is, especially, prevalent in developing countries in association with poor management practices and inadequate control measures [1]. An integrated approach is required for the effective control of the helminths and careful management of grazing lands including control of stocking rates and appropriate rotation strategies; however, problems have emerged with the use of anthelmintics, and development of resistance in helminths is a problem of major concern. In addition, recognition of the antigenic complexity of parasites has slowed vaccine development. For these various reasons, interest in the screening of medicinal plants for their anthelmintic activity remains of great scientific interest despite extensive use of synthetic chemicals in modern chemical practices worldwide. Majority of the ethnoveterinary medicine surveys and validation studies also indicate much wider and effective use of plants as anthelmintics compared to other diseases [2]. Many herbs belonging to the genus Abutilon are documented for their various medicinal benefits, but still they are not satisfactorily exploited. Our present study was done with the same aspiration to assess the anthelmintic activity of Abutilon theophrasti.

\section{METHODS}

Collection and authentication of plant material

A. theophrasti (Fig. 1) was collected from "Lower-Munda" District, Qazigund (J\&k) with the latitude $33.56^{\circ}$ and longitude $75.20^{\circ}$. The plant was identified and registered at Herbarium Center for Biodiversity and Taxonomy, "University of Kashmir," India. A voucher specimen (No.2113-KASH) (Fig. 1) was deposited in HCFBAT, University of Kashmir.

\section{Preparation of extracts}

The collected plant was washed with tap water and dried in shade. The dried plant samples were powdered and sieved to fine mesh and stored at room temperature before extraction. Methanol, distilled water, and hexane were used as solvents. Extraction was carried out by the maceration process. The extracts were concentrated to dryness using rotary evaporator

\section{Parasites}

Eggs to perform egg hatch test (EHT) and for the larvae culture were obtained from fecal samples rectally from Haemonchus contortusinfected sheep. Nematode infection was confirmed by egg counting test (eggs per gram feces) [3].

EHT

About $20 \mathrm{~g}$ feces were collected rectally from the infected sheep ( $>2000$ EPG). Feces were treated with water through a series of complied sieves $(500,150,90$, and $20 \mu \mathrm{m})$. Eggs which were retained at last sieve were obtained with a saturated saline solution by flotation. $100 \mu \mathrm{l}$ containing 100 eggs approximately were distributed in microdilution plates. Different crude stem extracts $(500,250,125,62.5$, and $31.25 \mathrm{mg} / \mathrm{ml}$ ) were added to the plates. Levamisole $(2 \mathrm{mg} / \mathrm{ml})$ was taken as a positive control and distilled water was taken as negative control. Total time taken to complete the experiment was $24 \mathrm{~h}$ and the temperature was maintained at $27^{\circ} \mathrm{C}$ [4]. Eggs and first stage larvae $\left(L_{1}\right)$ were counted as suggested by the World Association for the Advancement of Veterinary Parasitology (W.A.A.V.P). The obtained results were expressed as percentage inhibition of egg hatches.

\section{Larval motility test (LMT)}

About $20 \mathrm{~g}$ of feces were taken and homogenized at a concentration of about $2000 \mathrm{EPG}$ with the proportion of 1:2 v/v and incubated for 7 days at room temperature. The incubated material was moistened daily with 
distilled water. $\mathrm{L}_{3}$ larvae were collected by spontaneous migration with the aid of warm water $\left(37^{\circ} \mathrm{C}\right) .50 \mu \mathrm{L}$ suspension with $50 \mathrm{~L}_{3}$ was placed in microdilution plates. Crude extracts $(500,250,125,62.5$, and $31.25 \mathrm{mg} / \mathrm{ml}$ ) were added to these $\mathrm{L}_{3}$ containing microdilution plates and were incubated for next $24 \mathrm{~h}$ at $27^{\circ} \mathrm{C}$. Motile and non-motile $\mathrm{L}_{3}$ were counted by seeing keenly on the presence or absence of smooth sinusoidal movements. Levamisole $(2 \mathrm{mg} / \mathrm{ml})$ and distilled water were taken as positive and negative control, respectively [3]. Results were expressed as percentage inhibition of larval motility as a representation of three independent experiments performed in triplicate.

\section{RESULTS}

\section{EHT}

Percentage inhibition was concentration dependent. Methanolic stem extracts were more promising then aqueous and hexane extracts with inhibition percentages of $74.39,71.91,65.15,62.41$, and 47.38 on selected concentrations, respectively. Aqueous extracts displayed inhibition percentages of $72.5,70.7,63.94,59.32$, and 43.49. Hexane extracts showed inhibition percentages of 70.03, 64.84, 59.79, 53.14, and 48.16. Positive control levamisole $(2 \mathrm{mg} / \mathrm{ml})$ showed a inhibition of 98.6, while negative control (distilled water) showed a inhibition percentage of 1.67 (Fig. 2).

Data were statistically analyzed, and the level of significance was tested following the two-way analysis of variance.

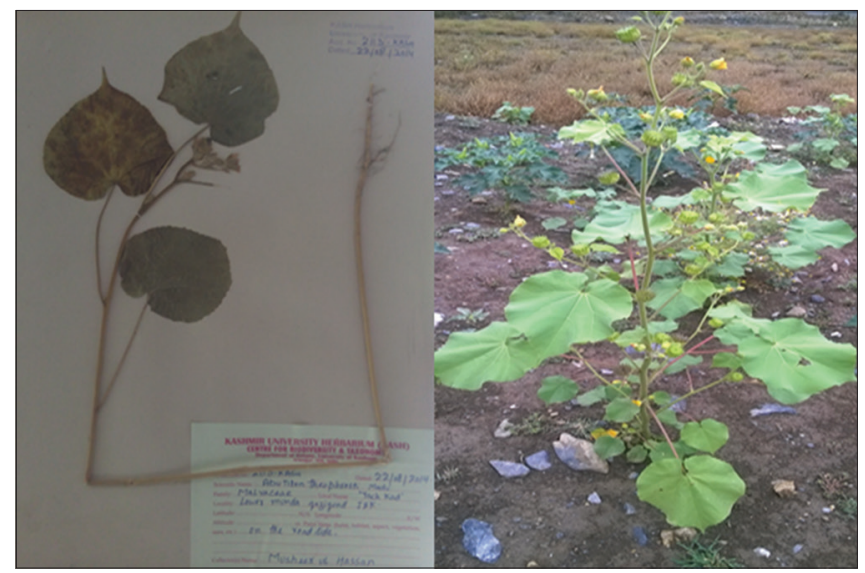

Fig. 1: Abutilon theophrasti
LMT

An inhibition percentage of all stem extracts of $A$. theophrasti were seen concentration dependent. Methanolic stem extracts showed inhibition percentages of $79.79,78,72.31,49.5$, and 28.47 on selected concentration, respectively. Aqueous extracts showed percentage inhibitions of $75.65,70.06,68.45,61.69$, and 54.13. Hexane extracts showed inhibition percentages of $71.28,70.98,57.86,33.1$, and 19.59 . Positive control levamisole $(2 \mathrm{mg} / \mathrm{ml})$ showed inhibition of 92.88 , while negative control (distilled water) showed inhibition percentage of 2.34 (Fig. 3).

Data were statistically analyzed, and the level of significance was tested following the two-way analysis of variance.

\section{DISCUSSION}

All the treatments based on extracts of $A$. theophrasti stem exhibited anthelmintic activity $(\mathrm{p} \leq 0.05)$. Methanolic stem extracts were found to exert potential inhibition activity against eggs compared to aqueous and hexane extracts. Maximum inhibition was seen at the highest concentration $(500 \mathrm{mg} / \mathrm{ml})$ in all selected extracts. Levamisole served as reference standard drug displayed inhibition of $98.6 \%$. Lowest inhibition was seen at a concentration of $31.25 \mathrm{mg} / \mathrm{ml}$ in all selected extracts; aqueous extracts were seen to show the lowest inhibition with inhibition percentage of $43.49 \%$.

Phytochemical investigations revealed the presence of flavonoid glycosides, catechins, anthocyanidins, sterols, triterpenes, tannins, vitamins, sugars, rubber-like substances, etc. [5-10]. Tannins have been reported to complex with polysaccharides. Condensed tannins have been determined to bind cell walls of ruminant bacteria preventing growth and protease activity [11]. One of the molecular actions of the tannins is complex with proteins through so-called nonspecific binding forces [12]. There are numerous reports indicating direct or indirect anthelmintic effects of condensed tannins, which are polyphenols $[13,14]$. Polyphenols have been attributed to the antihelmintic activity of white abrus [15]. Root and leaf extracts of $A$. theophrasti have been confirmed to possess antihelmintic activity [16], and hence, we find support to our study.

Variation in the anthelmintic activity of the extracts tested in the present study may be attributed to the disparity in the targets and qualitative and quantitative differences in the active phytochemicals of the stem. The targets to exert anthelmintic effects may differ in various parasite stages. Most of the screening in vitro tests are most easily applied to the

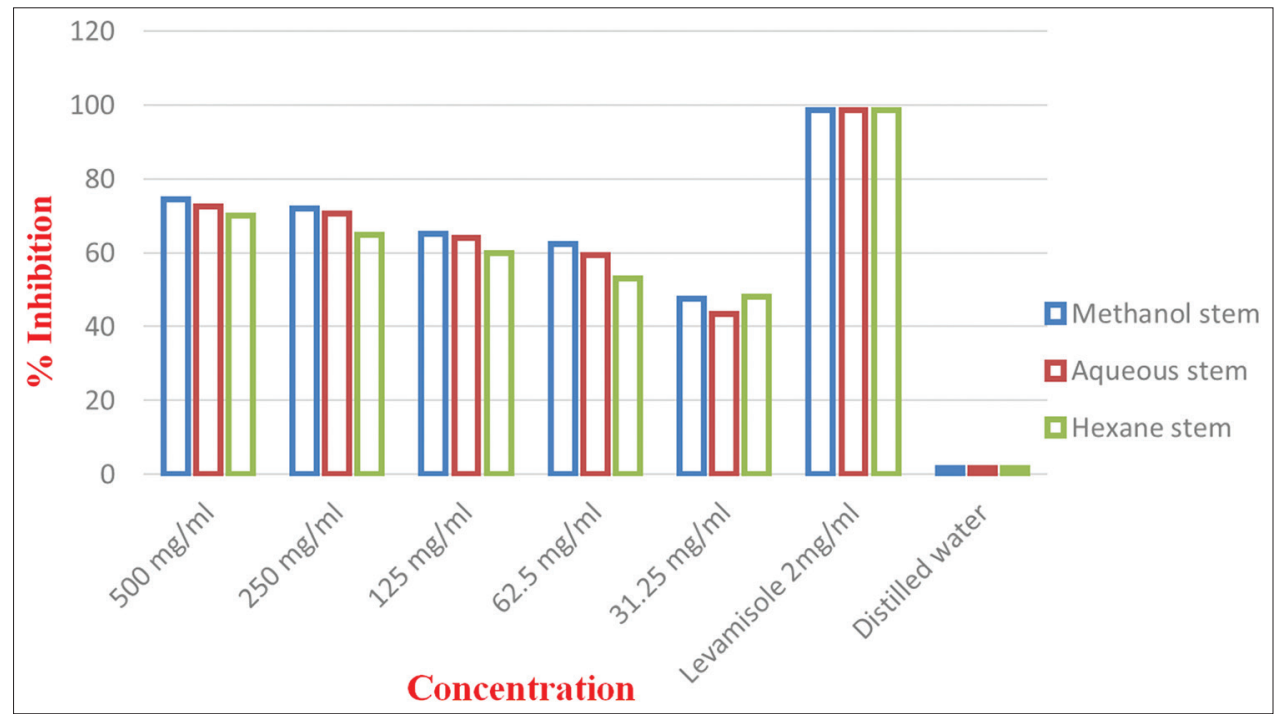

Fig. 2: Egg hatch test (stem) 


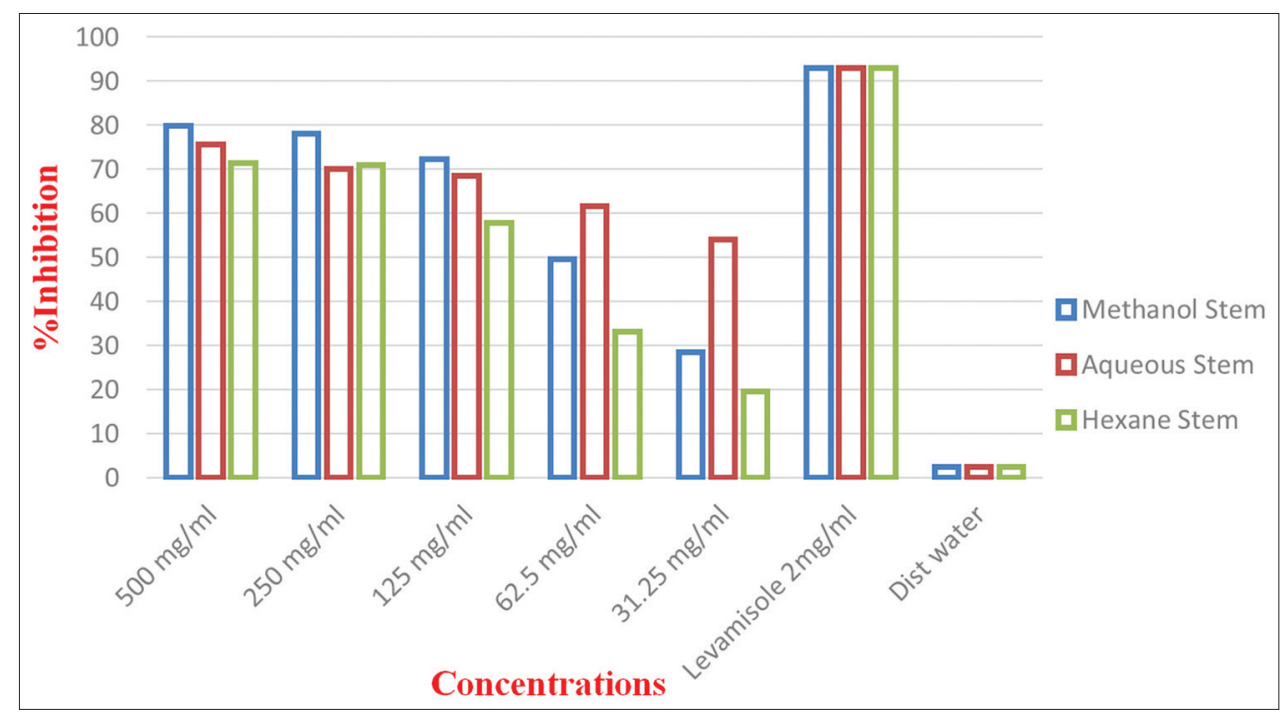

Fig. 3: Larval motility test (stem)

free-living stages of parasite species, i.e., eggs and larvae. The ultimate use of the anthelmintic will be directed at parasitic stages [17]. Certain guidelines have been designed for evaluating in vitro the anthelmintic efficacy of drugs that have been adopted by the W.A.A.V.P [18]. According to these guidelines, effective anthelmintic agents should inhibit worm egg hatching and larval motility by more than $90 \%$ and when inhibiting $80-90 \%$ should be considered moderately effective. Thus, our in vitro results obtained with $A$. theophrasti extract against $H$. contortus eggs and larvae, particularly in the higher dilutions, allow us to classify the tested extract as moderately effective. There is no clear evidence that synthetic anthelmintics leave no residues in meat that would pose potential public health hazards [19]. Henceforth, the identification of novel promising anthelmintic plant extracts such as A. theophrasti extract may contribute for the development of phytotherapic products that could be more cost-effective, safer, and more accessible and provide a lower risk of resistance than the conventional therapeutic arsenal currently employed.

\section{CONCLUSION}

The present study concludes with the finding that selected plant (A. theophrasti) is having potential anthelmintic activity against the eggs of H. contortus.

\section{ACKNOWLEDGMENT}

Authors are grateful to the Department of Zoology and Department of Biochemistry, Islamia College of Science and Commerce, Srinagar (Jammu and Kashmir), for providing the laboratory facilities to complete the research work.

\section{AUTHORS' CONTRIBUTIONS}

All the authors contributed equally to the conductance of the study, while as writing, and editing of the article was done by the first and corresponding author

\section{CONFLICTS OF INTEREST}

The authors declare that they have no conflicts of interest

\section{REFERENCES}

1. Dhar DN, Sharma RL, Bansal GC. Gastro-intestinal nematodes in sheep in Kashmir. Vet Para 1982;11:271-7.

2. Kundu SU, Roy SA, Nandi SU, Ukil BI, Lyndem LM. In vitro anthelmintic effects of Senna occidentalis (L.) link (Leguminosae) on rat tapeworm Hymenolepis diminuta. Int $\mathrm{J}$ Pharm Pharm Sci 2015;7:286-71.

3. Ueno H, Gonçalves PC. Manual Para Diagnóstico das Helmintoses de Ruminantes. Tokyo: Japan International Cooperation Agency; 1998.

4. Coles GC, Bauer C, Borgsteede FH, Geerts S, Klei TR, Taylor MA, et al. World association for the advancement of veterinary parasitology (WAAVP) methods for the detection of anthelmintic resistance in nematodes of veterinary importance. Vet Para 1992;44:35-44.

5. Paszkowski WL, Kremer RJ. Biological activity and tentative identification of flavonoid components in velvetleaf (Abutilon theophrasti Medik.) seed coats. J Chem Eco 1988;14:1573-82.

6. Matławska I, Sikorska M. Flavonoids from Abutilon theophrasti flowers. Acta Pol Pharm 2005;62:135-9.

7. Dinu M, Uivarosi V, Popescu L, Radulescu V, Arama CC, Nicolescu TO, et al. Proximate composition and some physico-chemical properties of Abutilon theophrasti (velvetleaf) seed oil. Rev de Chim (Bucuresti) 2010;61:50-4.

8. Balah MA, Nassar MI. Allelopathic constituents from Abutilon theophrasti aerial parts to other weeds. Res J Agric Biol Sci 2011;7:243-50.

9. Kiyamova SE, Khidyrova NK, Shakhidoyatov KM. Neutral compounds from leaves of plants of the family Malvaceae. II. Hibiscus tronuma A. Chem Nat Comp 2012;1:1-2.

10. Tian C, Wang M, Liu X, Wang H, Zhao C. HPLC quantification of nine chemical constituents from the five parts of Abutilon theophrasti Medic. J Chro Sci 2013;10:258-63.

11. Jones CG, Lawton JH, Shachak M. Organisms as ecosystem engineers. In: Ecosystem Management. New York, NY: Springer; 1994

12. Haslam E. Natural polyphenols (vegetable tannins) as drugs: Possible modes of action. J Nat Prod 1996;59:205-15.

13. Aerts RJ, Barry TN, McNabb WC. Polyphenols and agriculture: Beneficial effects of proanthocyanidins in forages. Agric Econ Environ 1999;75:1-2.

14. Niezen JH, Waghorn GC, Graham T, Carter JL, Leathwick DM. The effect of diet fed to lambs on the subsequent development of Trichostrongylus colubriformis larvae in vitro and on pasture. Vet Par 2002; 7:269-83.

15. Baby AA, Raphael KR. Antioxidant and anthelmintic potential of the stem and leaves of white abrus. Int J Pharm Pharm Sci 2014;5:126-9.

16. Hassan M, Reyaz AM, Huma H. In-vitro anthelmintic activity of different parts (leaf and root) of Abutilon theopharsti. World J Pharm Pharm Sci 2016;5:738-46.

17. Grady J, Kotze AC. Haemonchus contortus: In vitro drug screening assays with the adult life stage. Exp Para 2004;106:164-72.

18. Powers KG, Wood IB, Eckert J, Gibson T, Smith HJ. World association for the advancement of veterinary parasitology (WAAVP) guidelines for evaluating the efficacy of anthelmintics in ruminants (bovine and ovine). Vet Para 1982;10:265-84

19. Rodriguez A, Vigorito E, Clare S, Warren MV, Couttet P, Soond DR, et al. Requirement of bic/microRNA-155 for normal immune function. Sciences 2007;316:608-11. 